\title{
HOW WELL DOES COMPREHENSIVE INCOME MEASURE FUTURE FIRM PERFORMANCE COMPARED TO NET INCOME? EVIDENCE FROM TURKISH LISTED FIRMS
}

\author{
Ahmet ÖZCAN ${ }^{1}$
}

Başvuru Tarihi: 03.11.2015

Kabul Tarihi: 21.11.2015

\section{ABSTRACT}

The financial performance of the firms is one of the major concerns for the users of financial statements. Accounting standard setting bodies have encouraged firms to report comprehensive income which is believed to have much more value relevant information than traditional net income. The objective of this paper is to assess the usefulness of comprehensive income reporting and net income in explaining future firm performance. Based on a sample that includes 102 non-financial firms, the empirical analysis indicates that there are advantages of reporting of comprehensive income in predicting corporate financial performance. According to the empirical evidences, net income is better than comprehensive income in predicting future net income and operating income, while comprehensive income is better than net income in predicting future return on assets and return on equity. Keywords: International Financial Reporting Standards, Financial Performance, Comprehensive Income

JEL Codes: M40, M41, M49

\section{KAPSAMLI KÂR ŞIRKETIN GELECEKTEKİ PERFORMANSININ TAHMIN EDILMESINDE NET KÂRA GÖRE NE KADAR BAŞARILI? HALKA AÇIK TÜRK ŞIRKETLERINDEN BULGULAR}

\begin{abstract}
$\ddot{O} Z$
Firmaların finansal performansı mali tablo kullanıcılarının en çok ilgilendiği konular arasındadır. Muhasebe standardı belirleyici (yapıcı) kuruluşları firmaları net kârdan daha fazla değer ilgililiği olduğu düşünülen kapsamlı kârı raporlamaları konusunda yönlendirmektedir. Bu çalışmanın amacı, kapsamlı kârın ve net kârın firmanın gelecekteki performansinın tahmin edilmesindeki yararlılı̆̆ını değerlendirmektir. Finans sektöründe faaliyet göstermeyen 102 şirketin verilerine dayanan ampirik analizin sonuçlarına göre, kapsamlı kârın raporlanması şirketin gelecekteki performansının tahmin edilmesinde önemli avantajlar sunmaktadır. Ampirik analizin sonuçlarına göre, net kâr gelecekteki faaliyet kârının ve net kârın tahmin edilmesinde kapsamlı kâra göre daha
\end{abstract}

\footnotetext{
${ }^{1}$ Yrd. Doç. Dr., Adana Bilim ve Teknoloji Üniversitesi, Yönetim Bilişim Sistemleri Bölümü, aozcan@ adanabtu.edu.tr
} 
yüksek performans sergilerken, kapsamlı kâr ise gelecekteki varlık kârlılı̆̆ının ve öz sermaye kârlılığının tahmin edilmesinde net kâra göre daha yüksek performans sergilemektedir.

Anahtar Kelimeler: Uluslararası Finansal Raporlama Standartları, Finansal Performans, Kapsamlı Kâr

JEL Kodlarl: M40, M41, M49

\section{Introduction}

The financial information is one of the primary factors that affect decisions of the management of a firm, creditors, investors, suppliers, and governmental agencies. The financial information disclosed by the business entity is expected to be relevant, understandable, timely, comparable, and verifiable. The development of capital and money markets heavily depends on the quality of financial information issued by the business entities. The disclosure of accurate, relevant, and understandable accounting information remarkably enhances the functioning of the money and capital markets (Grüber, 2014:57).

In this study, the predictive power of comprehensive income and net income reporting in Turkey is examined. Firms listed in Borsa Istanbul adopted voluntarily international financial reporting standards in 2003 and the mandatory adoption of international financial reporting standards by Turkish listed firms began in 2005. The economic development in Turkey has changed the accounting practices from tax oriented to the investor and creditor oriented. With the advent of the new Commercial Code that came into effect on July 1, 2012, the effective application of International Financial Reporting Standards has gained too much more importance than before. Also, since 2013, International Financial Reporting Standards should be used by small and medium sized firms in the preparation of financial statements in Turkey. In addition to these, Turkey's European Union integration process is one of the main factors that change the accounting standards and applications in the country (Balsari and Varan, 2014).

IAS 1 Presentation of Financial Statements was revised in September 2007. International Accounting Standards Board has revised IAS 1 Presentation of Financial Statements to yield more relevant financial information and enhance the quality of financial information disclosed by the business entities. A revised IAS 1 Presentation of Financial Statements changed the titles of financial statements disclosed by the business entities. Under the revised IAS 1, income statement has been renamed as 'Statement of Comprehensive Income'. The revised IAS 1 Presentation of Financial Statements mandates that a new financial 
performance measure, comprehensive income, be disclosed in the financial statements of business entity. According to IAS 1 Presentation of Financial Statements, comprehensive income not only encompasses revenues, gains, expenses and losses reported in traditional income statement but also all gains and losses that influence the stockholders equity (Kieso et al., 2011). In the current business climate, the comprehensive income plays a pivotal role in assessing the reporting entity's financial performance. The recent revision of IAS 1 Presentation of Financial Statements has motivated researchers to investigate the value added of comprehensive income.

The financial performance of the corporations is among the major concerns for the users of financial statements. The way of measuring financial performance of corporation is currently one of the most debated topics in the business environment. Accounting theorists have put forward opinions for the nature of the income earned by the corporations and developed methods to accurately measure the net income of the corporation. In the modern business era, the primary challenge that accounting standard setting bodies face is to accurately determine the value of implicit economic value of the business entities (Kanagaretnam et al., 2009).

The predictive ability of comprehensive income and other financial performance measures has been well documented for the developed economies (Dhaliwal et al., 1999; Choi et al., 2007; Biddle and Choi, 2006). However, there are few studies regarding the predictive ability comprehensive income for the developing economies. This study seeks to address the question of whether comprehensive income provides the financial markets with value relevant information related with the future corporate financial performance of business entities operating in Turkey.

This paper is organized as follows. First of all, the rationale for comprehensive income reporting is examined. Secondly, the previous research studies will be reviewed. Thirdly, the sample selection, empirical research design, and data will be presented. In the fourth section, the results of empirical research will be reported and discussed. The final section of the study concludes the paper, and makes recommendations for future research studies.

\section{The Background of Comprehensive Income Reporting and Past Literature}

From the perspective of users of financial statements, income statement is the most important financial statement disclosed by business entities. Hence, all accounting data associated with profit and loss should appear on the income statement. Accounting standard 
setting bodies aim to enhance the understandability and comparability of income statement for creditors, investors and other users.

Accounting Standards Board, an accounting standards setting body of the United Kingdom, is the first standard setting body that introduced the concept of the comprehensive income. FRS (Financial Reporting Standard) 3 Reporting Financial Performance issued by Accounting Standards Board in 1992 requires the reporting entities to prepare a statement of total recognized gains and losses, a supplement to the profit and loss account. Under FRS 3, total recognized gains and losses starts with net income, and includes other transitory items such as currency translation difference, and unrealized surplus on the revaluation of fixed assets (FRS 3, 1992).

US Financial Accounting Standards Board issued Statement of Financial Accounting Standards 130. SFAS 130 that came into effect in 1997 establishes the presentation of comprehensive income and its components in the firms' financial statements. Before the effective date of SFAS 130, foreign currency translation adjustments, unrealized gains and losses on investments in debt or equity securities, and minimum pension liability adjustments were reported under the stockholders' equity. SFAS 130 require the reporting entities to report these accounts as a component of comprehensive income. SFAS 130 requires the components of comprehensive income to be presented separately from each other (SFAS 130, paragraph 13). US Financial Accounting Standards Board defines the comprehensive income as follows: 'the change in stockholders' equity of business entity during the accounting period arising from transactions with non-owner sources' (SFAS 130, paragraph 70).

International Accounting Standards Board (IASB) and US Financial Accounting Standards Board (FASB), the primary accounting standard setting bodies, have decided to collaborate with each other on financial performance reporting process in 2004. Undoubtedly, the harmonization of financial reporting standards promotes the comparability of accounting information across countries, facilitates financial statement analysis and brings more clarity in the dynamic relationship that exists between financial statements (Schroeder et al., 2001). Joint International Group on Performance Reporting, in the interest of global convergence of financial reporting standards, has been established by IASB and FASB to help them in establishing standards for presenting information needed to evaluate the business entities' 
financial performance (IASB, 2004a). The main motivation for the establishment of Joint International Group on Performance Reporting is that there is no consensus on the components of business entities' financial performance. As a result of joint project, International Accounting Standards Board has revised IAS 1 Presentation of Financial Statements in order to comply with US standard, SFAS 130 Reporting Comprehensive Income.

IAS 1 Presentation of Financial Statements provides two options of reporting revenues, expenses and comprehensive income items. Business entities can present profit or loss and items of other comprehensive income in either:

a) in a single statement of comprehensive income, in which case the statement of comprehensive income displays all items of income and expense recognized.

b) in two separate statements - an income statement and a statement of comprehensive income

Comprehensive income is equal to the sum of profit and other comprehensive income. IAS 1 states that the components of other comprehensive income are as follows (IAS 1, paragraph 7):

- changes in revaluation surplus ( IAS 16, and IAS 38)

- gains and losses arising from translating the financial statements of a foreign operation (IAS 21)

- remeasurement of defined benefit plans (IAS 19)

- gains and losses from investments in equity instruments measured at fair value through other comprehensive income (IAS 39)

There is a never ending debate over the usefulness of comprehensive income between opponents and proponents of comprehensive income reporting. Proponents of comprehensive income reporting argue that comprehensive income reporting significantly increases the transparency of financial statements disclosed by firms. Proponents of comprehensive income reporting also state that comprehensive income reflects all sources of value creation (Chambers et al., 2007). The unrealized gains or losses excluded from the net income may be associated with core business operations conducted by firms (Maines and McDaniel, 2000). In addition, Keating (1999) put forward that unrealized gains or losses excluded from the net income 
eventually become realized and the disclosure of these items allows the financial statement users to analyze future cash flow of a firm. Furthermore, Hirst and Hopkins (1998), Maines and McDaniel (2000) and Hunton et al. (2006) state that the disclosure of comprehensive income components significantly makes earnings management more transparent. Furthermore, the proponents of comprehensive income reporting assert that with the introduction of comprehensive income reporting, financial statement users can make more informed decisions related to future corporate performance (Biddle and Choi, 2006; Choi et al., 2007).

Opponents of comprehensive income reporting state that comprehensive income reporting fails to reflect permanent earning power of a firm, since it includes non-recurring items and non-core business operations (Kanagaretnam et al., 2009). The reporting of comprehensive income makes earnings more volatile than net income, resulting from non-core business items (Yen et al., 2007). Moreover, McCoy et al. (2009) state that comprehensive income items could be highly volatile and thus mitigate its usefulness for forecasting the firm value. Skinner (1999) reports that accounting adjustments for comprehensive income items are highly difficult to explain economically and many financial analysts deliberately ignore the components of comprehensive income in the prediction of future financial performance.

In this part of the study, previous research studies are presented. Most of previous studies focus on the usefulness and predictive power of comprehensive income reporting in the developed markets. As previous research studies have provided mixed results and failed to correctly assess the usefulness of comprehensive income and net income in explaining future firm performance, further research studies are needed to compare the usefulness of comprehensive income and net income in explaining future firm performance. In Turkey, there are a limited number of studies regarding whether comprehensive income reported by the business entities provides the money and capital markets with value relevant information related with the financial performance of business entities.

Zülch, and Pronobis (2010) investigate the predictive power of the components of comprehensive income for the entity's future financial performance. The final sample used in the empirical analysis consists of 71 companies operating in Germany, and time period for analysis is between 1998 and 2007. They found no evidence that comprehensive income reported by the entities has a better predictive power for entity's future financial performance 
than net income.

Choi et al. (2007) examine the predictive power of comprehensive income disclosures. According to the results of the empirical analysis, comprehensive income disclosed by the entities has a power to predict future financial performance and the stock exchange prices. The final sample they used in the empirical analysis consists of 3716 entities, and business entities operating in the financial industry are excluded from the sample due to different accounting rules and disclosure requirements.

Dhaliwal et al. (1999) compare the ability of comprehensive income and net income to predict the future corporate performance. They conclude that comprehensive income is not a better predictor of future corporate performance than net income and state that the marketable securities adjustments, one of the components of comprehensive income, may enhance the ability of comprehensive income to summarize future financial performance. Biddle and Choi (2006) state that comprehensive income provides greater decision usefulness than net income in predicting future net income and comprehensive income and the separately reporting of comprehensive income components have incremental value relevance.

Using sample firms operating in New Zealand, Cahan et al. (2000) report that comprehensive income is much more relevant than net income and the individual components of comprehensive income do not provide value relevant information to the users of financial statements. Kanagaretnam et al. (2009) investigate whether the components of other comprehensive income reported by Canadian firms have value relevance. They found that aggregate comprehensive income is much more closely associated with stock exchange prices and returns than net income.

Cheng et al. (1993) analyze the usefulness of three financial performance measures: comprehensive income, net income and operating income. Based on a sample that includes 922 firms from US, they found that operating income and net income are much more useful in clarifying abnormal returns than comprehensive income. By using data of ninety-two Australian non-financial firms, Brimble and Hodgson (2005) find that net income better forecasts future firm performance than comprehensive income and recommend that accounting standard setting bodies should focus on items which are closely associated with core business activities in order to enhance the ability of comprehensive income to predict future financial performance. 
In Turkey, there is very limited research addressing whether future firm performance is more highly associated with net income or comprehensive income. Demir et al. (2013) compare the ability of comprehensive income and net income to summarize stock returns, operating cash flows and market value of equity. According to the results of empirical analysis, they state that comprehensive income is superior to net income in terms of performance measurement. Based on a sample that includes thirty seven firms listed on Borsa Istanbul, Köse and Gürkan (2014) report that comprehensive income is significantly useful in explaining market value of firms. Using the empirical data retrieved from Borsa Istanbul for the period 2004-2005, Cihangir (2006) states that net income is better than comprehensive income in explaining stock price changes.

\section{Research Design}

\subsection{Data and Sample}

This section is devoted to the characteristics of data and samples. The sample is obtained from the public disclosure platform ${ }^{2}$. The sample used in the empirical analysis covers the period from 2010 to 2014. The sample includes the listed companies on the Borsa Istanbul. To be included in the sample, a company must be listed on Borsa Istanbul, have positive book value of equity, and its financial statements must be available in the website of public disclosure platform. All observations that do not have other comprehensive income items are excluded from the sample. This is because the empirical analysis of this study focuses on the difference between comprehensive income and net income. Companies operating in the financial industry are excluded in the sample since the balance sheet structures and accounting rules are prominently different for financial industry. Table 1 presents the industrial classification of sample companies. As can be seen from table 1, the most heavily represented industry in the sample is fabricated metal products, machinery and equipment (35\%), followed by non-metallic mineral products $(17 \%)$.

\section{Table 1 Industrial Classification of Sample Companies}

\footnotetext{
${ }^{2}$ Public Disclosure Platform is the website in which financial statements of companies are released to the public.
} 


\begin{tabular}{lcc}
\hline Sectors & $\begin{array}{c}\text { Number of } \\
\text { Companies }\end{array}$ & Percentage \\
\hline Food, Beverage and Tobacco & 17 & $16 \%$ \\
Non- Metallic Mineral Products & 18 & $17 \%$ \\
Fabricated Metal Products, Machinery and & 35 & $35 \%$ \\
Equipment & 17 & $16 \%$ \\
Chemicals, Petroleum Rubber and Plastic Products & 5 & $5 \%$ \\
Basic Metal Industries & 8 & $8 \%$ \\
Paper and Paper Products, Printing and Publishing & 2 & $3 \%$ \\
Wood Products & 102 & $100 \%$ \\
\hline Total & & \\
\hline
\end{tabular}

Data variables are collected from financial statements disclosed by the business entities. In this study, six monthly financial statements are used. The sample consists of 798 firm-year observations representing 102 firms. This broad sample is the representative of large manufacturing companies operating in the Turkish economy.

\subsection{Empirical Models}

To analyze the usefulness of comprehensive income in forecasting future financial performance, the relationship that exists between six-month ahead financial performance measures and comprehensive income in the current period is investigated. The financial performance of sample companies is examined and measured with different perspectives. That is why four different measures are used to assess the financial performance of sample firms. These measures are net income, return on assets, return on equity, and operating income. The following equations that investigate whether net income or comprehensive income better forecasts future corporate performance are developed;

(1) Net income $(\mathrm{t}+1): \mathrm{c}_{0}+\mathrm{c}_{1} \mathrm{Net}_{\text {Income }}+\mathrm{c}_{2}$ Comprehensive Income $_{\mathrm{t}}+\varepsilon_{\mathrm{t}}$

(2) Return on assets ${ }_{(t+1)}: c_{0}+c_{1}$ Net Income ${ }_{t}+c_{2}$ Comprehensive Income $t+\varepsilon_{t}$

(3) Return on equity $(\mathrm{t}+1): \mathrm{c}_{0}+\mathrm{c}_{1} \mathrm{Net}_{\text {Income }}+\mathrm{c}_{2}$ Comprehensive Income $_{\mathrm{t}}+\varepsilon_{\mathrm{t}}$ 
(4) Operating income ${ }_{(t+1)}: \mathrm{c}_{0}+\mathrm{c}_{1}$ Net Income $\mathrm{t}_{\mathrm{t}}+\mathrm{c}_{2}$ Comprehensive Income $\mathrm{t}_{\mathrm{t}}+\varepsilon_{\mathrm{t}}$

In these equations, future corporate performance measured by net income, return on equity, return on equity, and operating income is explained by two accounting variables: net income and comprehensive income. The subscript $t$ and $t+1$ stand for the time period.

\section{Table 2 Definition of Variables}

\begin{tabular}{|l|l|}
\hline $\mathrm{NI}_{(\mathrm{t}+1)}$ & $\begin{array}{l}\text { the net income at the end of the six-month period } \mathrm{t}+1 \text { deflated by the number of } \\
\text { outstanding shares }\end{array}$ \\
\hline $\mathrm{NI}_{\mathrm{t}}$ & $\begin{array}{l}\text { the net income at the end of the six-month period } \mathrm{t} \text { deflated by the number of } \\
\text { outstanding shares }\end{array}$ \\
\hline $\mathrm{CI}_{\mathrm{t}}$ & $\begin{array}{l}\text { the comprehensive income at the end of the six-month period } \mathrm{t} \text { deflated by the } \\
\text { number of outstanding shares }\end{array}$ \\
\hline $\mathrm{ROA}_{(\mathrm{t}+1)}$ & $\begin{array}{l}\text { the return on assets at the end of the six-month period } \mathrm{t}+1 \text { deflated by the number } \\
\text { of outstanding shares }\end{array}$ \\
\hline $\mathrm{ROE}_{(\mathrm{t}+1)}$ & $\begin{array}{l}\text { the return on equity at the end of the six-month period } \mathrm{t}+1 \text { deflated by the number } \\
\text { of outstanding shares }\end{array}$ \\
\hline $\mathrm{OI}_{(\mathrm{t}+1)}$ & $\begin{array}{l}\text { the operating income at the end of the six-month period } \mathrm{t}+1 \text { deflated by the } \\
\text { number of outstanding shares }\end{array}$ \\
\hline
\end{tabular}

Equations 1, 2, 3, and 4 are tested by comparing the ability of net income and comprehensive income to forecast future levels in net income, return on assets, return on equity and operating income. In this context, the equations used in the empirical analysis parallel with those of Biddle and Choi (2006), Kanagaretnam et al. (2009), Pronobis and Zülch (2010) and Dhaliwal et al. (1999).

\section{Empirical Results}

\subsection{Descriptive Statistics}

In this part of the study, the descriptive statistics of the variables and correlation matrix are given to provide the prominent characteristics of the analyzed data. Table 3 presents 
descriptive statistics of the research variables used in the empirical analysis. Despite the adverse impacts of credit crunch on the global economy, the majority of sample companies are profitable over the period 2010-2014. Table 3 indicates that the standard deviation of net income deflated by the outstanding shares is greater than standard deviation of comprehensive income deflated by the outstanding shares, return on assets and return on equity. Generally speaking, the mean of $\mathrm{NI}_{(\mathrm{t}+1)}$ is higher than the mean of comprehensive income, return on assets and return on equity. It is worth mentioning that the amount of other comprehensive income items reported by some of companies in the sample negatively affects the companies' net income.

Table 3 Descriptive Statistics for Sample Firms

\begin{tabular}{lccccc}
\hline Variables & Mean & Standard Deviation & $25 \%$ & $50 \%$ & $75 \%$ \\
\hline $\mathrm{NI}_{(\mathrm{t}+1)}$ & 0.4007 & 1.5488 & -0.0297 & 0.0878 & 0.4712 \\
$\mathrm{NI}_{(\mathrm{t})}$ & 0.3493 & 1.3180 & -0.0298 & 0.0842 & 0.4139 \\
$\mathrm{CI}_{(\mathrm{t})}$ & 0.2306 & 0.5622 & -0.0225 & 0.0932 & 0.3552 \\
$\mathrm{ROA}_{(\mathrm{t}+1)}$ & 0.0237 & 0.0923 & -0.0082 & 0.0245 & 0.0624 \\
$\mathrm{ROE}_{(\mathrm{t}+1)}$ & 0.0322 & 0.2154 & -0.0154 & 0.0568 & 0.1278 \\
$\mathrm{OI}_{(\mathrm{t}+1)}$ & 0.6328 & 1.6347 & 0.0900 & 0.1773 & 0.7419 \\
\hline
\end{tabular}

Table 4 displays the correlation matrix for the research variables used in the empirical analysis. As can be expected, all financial performance measures are positively correlated with each other. All of these correlation coefficients are significantly different from zero (p-value $<$ 0.01). The amount of other comprehensive income items plays a substantial role in the level of correlation that exists between $\mathrm{NI}_{(\mathrm{t})}$ and $\mathrm{CI}_{(\mathrm{t})}$.

Table 4 Correlation Matrix and Pearson Correlation Coefficients

\begin{tabular}{lllllll}
\hline & $\mathrm{NI}_{(\mathrm{t}+1)}$ & $\mathrm{NI}_{(\mathrm{t})}$ & $\mathrm{CI}_{(\mathrm{t})}$ & $\mathrm{ROA}_{(\mathrm{t}+1)}$ & $\mathrm{ROE}_{(\mathrm{t}+1)}$ & $\mathrm{OI}_{(\mathrm{t}+1)}$ \\
\hline $\mathrm{NI}{ }_{(\mathrm{t}+1)}$ & 1.0000 & & & & \\
p-value & 0.0010 & & & & \\
& & & & & \\
\hline
\end{tabular}




\begin{tabular}{|c|c|c|c|c|c|c|}
\hline $\mathrm{NI}_{(\mathrm{t})}$ & 0.6425 & 1.0000 & & & & \\
\hline p-value & 0.0010 & & & & & \\
\hline $\mathrm{CI}_{(\mathrm{t})}$ & 0.4316 & 0.5554 & 1.0000 & & & \\
\hline p-value & 0.0000 & 0.0030 & & & & \\
\hline $\operatorname{ROA}_{(t+1)}$ & 0.4568 & 0.2951 & 0.3413 & 1.0000 & & \\
\hline p-value & 0.0010 & 0.0000 & 0.0000 & & & \\
\hline $\operatorname{ROE}_{(t+1)}$ & 0.2974 & 0.2555 & 0.3337 & 0.6143 & 1.0000 & \\
\hline$p$-value & 0.0010 & 0.0000 & 0.0010 & 0.0020 & & \\
\hline $\mathrm{OI}_{(\mathrm{t}+1)}$ & 0.3174 & 0.1511 & 0.1959 & 0.3201 & 0.2356 & 1.0000 \\
\hline p-value & 0.0000 & 0.0010 & 0.0000 & 0.0010 & 0.0020 & \\
\hline
\end{tabular}

\subsection{Empirical Results of Regression Analysis}

In this section of study, the results of empirical analysis are discussed. The results of regression analysis are reported below. In the table 5, equation (1), the coefficient on comprehensive income is positive and significant at the $1 \%$ level $(\mathrm{t}$-stat. $=3.33, \mathrm{p}<0.001)$, indicating that comprehensive income reported by the sample companies has strong explanatory power in explaining future corporate performance. According to the results of the regression, the adjusted $\mathrm{R}^{2}$ for the equation (1) is approximately $42 \%$. The results of regression analysis for equation (1) differ from the results in Biddle and Choi (2006), where comprehensive income has more predictive power than net income. However, the results of regression analysis correspond to the results of Dhaliwal et al. (1999), Pronobis and Zülch (2010) and Kanagaretnam et al.(2009) who find that net income better forecasts future net income than comprehensive income.

Table 6 presents the estimation results for equation (2) which regresses return on assets on net income and comprehensive income. As shown in table 6, equation (2), the coefficients on $\mathrm{NI}_{(\mathrm{t})}$ and $\mathrm{CI}_{(\mathrm{t})}$ are positive and significant at the $1 \%$ level. The results also indicate that comprehensive income is a better indicator of future return on assets than net income and $13.26 \%$ of the total variation in the $\mathrm{ROA}_{(\mathrm{t}+1)}$ is explained by $\mathrm{NI}_{(\mathrm{t})}$ and $\mathrm{CI}_{(\mathrm{t})}$. 
The results of predicting future return on equity reported in Table 7 reveal that comprehensive income is apparently superior over net income in predicting the future return on equity. The coefficients on $\mathrm{NI}_{(\mathrm{t})}$ and $\mathrm{CI}_{(\mathrm{t})}$ are positive and significant at the $1 \%$ level. The coefficient for comprehensive income is 0.1063 and the coefficient for net income is 0.0166 . The equation (3) has the lowest adjusted $\mathrm{R}^{2}(11.63 \%)$ among the all.

Table 5 The Results of Regression Analysis for the Equation (1)

\begin{tabular}{llc}
\hline Variable $^{\mathrm{b}}$ & Coefficient & t-value \\
\hline Intercept & 0.0929 & $2.060^{\mathrm{c}}$ \\
$\mathrm{NI}_{(\mathrm{t})}$ & 0.6845 & $17.960^{\mathrm{c}}$ \\
$\mathrm{CI}_{(\mathrm{t})}$ & 0.2979 & $3.330^{\mathrm{c}}$ \\
$\mathrm{n}$ & 798 & \\
Adjusted $\mathrm{R}^{2}$ & $41.94 \%$ & \\
\hline
\end{tabular}

Notes:

a. Net income $(\mathrm{t}+1): \mathrm{c}_{0}+\mathrm{c}_{1} \mathrm{Net}_{\text {Income }}+\mathrm{c}_{2}$ Comprehensive Income $\mathrm{t}_{\mathrm{t}}+\varepsilon_{\mathrm{t}}$

b. See table 2 for the definitions of variables.

c. significantly different from 0 at $1 \%$ level.

Table 6 The Results of Regression Analysis for the Equation (2)

\begin{tabular}{llc}
\hline Variable $^{\mathrm{b}}$ & Coefficient & t-value \\
\hline Intercept & 0.0103 & $3.1100^{\mathrm{c}}$ \\
$\mathrm{NI}(\mathrm{t})$ & 0.0107 & $3.8400^{\mathrm{c}}$ \\
$\mathrm{CI}_{(\mathrm{t})}$ & 0.0421 & $6.4600^{\mathrm{c}}$ \\
$\mathrm{n}$ & 798 & \\
Adjusted $\mathrm{R}^{2}$ & $13.26 \%$ & \\
\hline
\end{tabular}

Notes: 
a. Return on assets ${ }_{(\mathrm{t}+1)}: \mathrm{c}_{0}+\mathrm{c}_{1}$ Net Income ${ }_{t}+\mathrm{c}_{2}$ Comprehensive Income $\mathrm{I}_{\mathrm{t}}+\varepsilon_{\mathrm{t}}$

b. See table 2 for the definitions of variables.

c. significantly different from 0 at $1 \%$ level.

Table 7 The Results of Regression Analysis for the Equation (3)

\begin{tabular}{lll}
\hline Variable $^{\mathrm{b}}$ & Coefficient & t-value \\
\hline Intercept & 0.0019 & $0.2400^{\mathrm{c}}$ \\
$\mathrm{NI}(\mathrm{t})$ & 0.0166 & $2.5300^{\mathrm{c}}$ \\
$\mathrm{CI}_{(\mathrm{t})}$ & 0.1063 & $6.9300^{\mathrm{c}}$ \\
$\mathrm{n}$ & 798 & \\
Adjusted $\mathrm{R}^{2}$ & $11.63 \%$ & \\
\hline
\end{tabular}

Notes:

a. Return on equity $(\mathrm{t}+1): \mathrm{c}_{0}+\mathrm{c}_{1}$ Net Income $\mathrm{t}_{\mathrm{t}}+\mathrm{c}_{2}$ Comprehensive Income $\mathrm{e}_{\mathrm{t}}+\varepsilon_{\mathrm{t}}$

b. See table 2 for the definitions of variables.

c. significantly different from 0 at $1 \%$ level.

Table 8 The Results of Regression Analysis for the Equation (4)

\begin{tabular}{llc}
\hline Variable $^{\mathrm{b}}$ & Coefficient & t-value \\
\hline Intercept & 1.0380 & $9.39^{\mathrm{c}}$ \\
$\mathrm{NI}(\mathrm{t})$ & .5678 & $8.72^{\mathrm{c}}$ \\
$\mathrm{CI}_{(\mathrm{t})}$ & .1478 & $2.26^{\mathrm{c}}$ \\
$\mathrm{n}$ & 798 & \\
Adjusted $\mathrm{R}^{2}$ & $47.71 \%$ & \\
\hline
\end{tabular}

Notes: 
a. Operating Income $(\mathrm{t}+1): \mathrm{c}_{0}+\mathrm{c}_{1} \mathrm{Net}_{\text {Income }}+\mathrm{c}_{2}$ Comprehensive Income $\mathrm{t}_{\mathrm{t}}+\varepsilon_{\mathrm{t}}$

b. See table 2 for the definitions of variables.

c. significantly different from 0 at $1 \%$ level.

The regression result for predicting operating income is presented in the table 8 . The coefficients on net income and comprehensive income are positive, as expected, and significant at $1 \%$ level. The results presented in Table 8 suggest that net income is a better indicator of future operating income than comprehensive income, confirming the findings of previous studies (Dhaliwal et al., 1999). This result is expected because comprehensive income includes noncore and nonrecurring earnings. The results of regression analysis contradict Biddle and Choi (2006) who find that comprehensive income is superior to net income in predicting future operating income. The equation (4) has the highest adjusted $\mathrm{R}^{2}(47.71 \%)$.

Considered altogether, the results of estimating models suggest that net income provides the greatest predictive power for future net income and operating income and comprehensive income provides the greatest the predictive power for future return on equity and return on assets. The findings of the regression models for estimating models also state that net income and comprehensive income are superior for different equations. The conflicting results of estimation models offer no clear evidence on whether net income or comprehensive income is a better predictor of future corporate performance.

It is worth mentioning that even though aggregate comprehensive income is one of the vital financial performance measures, the users of financial statements should have information associated with the components of comprehensive income to make rational and accurate decisions. The results of empirical analysis prove that different definitions of income may provide different insights to the users of financial statements about future corporate performance.

\section{Concluding Remarks}

Comprehensive income is increasingly becoming a vital component of financial reporting environment. Since the introduction of the comprehensive income, it has grabbed the attention of investors, creditors, stockholders, government authorities, and other financial statements users. 
This study primarily aims to contribute to the existing literature by empirically researching the ability of net income and comprehensive income to predict future levels in net income, return on assets, return on equity and operating income. The empirical evidence supports the assertion that there are advantages of reporting comprehensive income in predicting corporate financial performance. According to the empirical evidences reported in this paper, net income is better than comprehensive income in forecasting future operating income and net income, while comprehensive income is better than net income in forecasting future return on assets and return on equity.

This study evaluates the credibility of comprehensive income through predictability analysis. The findings of the empirical analysis support the requirement that business entities operating in Turkey report comprehensive income. The empirical evidence of this study also supports the conclusion that net income and comprehensive income provide valuable insights into corporate financial performance.

The results of this study are critically important for the accounting standard setting bodies such as IASB, FASB and local regulatory bodies and may also be helpful for financial market participants to figure out corporate financial performance from a different perspective. 


\section{REFERENCES}

ASB (1992). FRS 3 Reporting Financial Performance, available at: https://frc.org.uk/Our-Work/CodesStandards/Accounting-and-Reporting-Policy/Standards-in-Issue/FRS-3-Reporting-FinancialPerformance.aspx (accessed 15 March 2015).

Balsari, C. K. and Varan, S. (2014). IFRS implementation and studies in Turkey. Accounting and Management Information Systems, Vol. 13 No.2, pp. 373-399.

Biddle, G. C. and Choi, J. H. (2006). Is comprehensive income useful?. Journal of Contemporary Accounting and Economics, Vol. 2 No. 1, pp. 1-32.

Brimble, M. and Hodgson, A. (2005). The value relevance of comprehensive income and components for industrial firms. Working Paper, Griffith University and Amsterdam Business School Universiteit of Amsterdam.

Cahan, S. F., Courtenay, S. M., Gronnewoller, P. L., and Upton, D. R. (2000). Value relevance of mandated comprehensive income disclosures. Journal of Business Finance and Accounting, Vol. 27 No.9-10, pp.1233-1265.

Chambers, D., Linsmeier, T. J., Shakespeare, C., and Sougiannis, T. (2007). An evaluation of SFAS No. 130 comprehensive income disclosures. Review of Accounting Studies, Vol.12 No. 4, pp. 557-593

Cheng, C. S., Cheung, J. K., and Gopalakrishnan, V. (1993). On the usefulness of operating income, net income and comprehensive income in explaining security returns. Accounting and Business Research, Vol. 23 No. 91, pp. 195-203.

Cihangir, E. (2006). The value relevance of comprehensive income: An application at Istanbul stock exchange. Unpublished Master Thesis. Dokuz Eylül University. İzmir, Türkiye.

Choi, J.H., Das, S., and Zang, Y. (2007). Comprehensive income, future earnings and market mispricing. Working Paper, Seoul National University, March 2007.

Demir, V., Bahadır, O., and Öncel, A.G. (2013). En iyi finansal performans ölçümü nedir? Kapsamlı kar'a karşılık net kar: Türkiye'de elde edilen bulgular. İktisat İşletme ve Finans, 28(323), 73-96.

Dhaliwal, D., Subramanyam, K. R., and Trezevant, R. (1999). Is comprehensive income superior to net income as a measure of firm performance?. Journal of Accounting and Economics, Vol. 26 No. 1, pp. 43-67.

Epstein, B.J. and Jermakowicz, E.K. (2008). Wiley IFRS 2008: Interpretation and Application of International Accounting and Financial Reporting Standards, 5th ed. John Wiley and Sons, New Jersey, NJ.

Financial Accounting Standards Board (1997). Statement of Financial Accounting Standard No. 130: Reporting Comprehensive Income.

Grüber, S. (2014). Intangible Values in Financial Accounting and Reporting: An Analysis from the Perspective of Financial Analysts, Springer.

Hirst, D.E. and Hopkins, P.E. (1998). Comprehensive income disclosures and analysts' valuation judgments, available at SSRN: http://ssrn.com/abstract=63588 or http://dx.doi.org/10.2139/ssrn.63588 (accessed 18 March 2015). 
Hunton, J. E., Libby, R., and Mazza, C. L. (2006). Financial reporting transparency and earnings management. The Accounting Review, Vol. 81 No. 1, pp. 135-157.

International Accounting Standards Board (2007). IAS 1 Presentation of Financial Statements.

Kanagaretnam, K., Mathieu, R., and Shehata, M. (2009). Usefulness of comprehensive income reporting in Canada. Journal of Accounting and Public Policy, Vol. 28 No. 4, pp. 349-365.

Keating, M. (1999). An analysis of the value of reporting comprehensive income. Journal of Accounting Education, Vol. 17 No. 2, pp. 333-339.

Kieso, D. S., Weygandt, J. J., and Warfield, T. D. (2011). Intermediate Accounting IFRS Edition. John Wiley and Sons, New Jersey, NJ.

Köse, Y., and Gürkan, S. (2014). Diğer kapsamlı gelir ile işletmenin piyasa değeri arasındaki ilişki: Borsa İstanbul'da işlem gören şirketlerde bir araştırma. World of Accounting Science, 16(1).

Maines, L. A. and McDaniel, L. S. (2000). Effects of comprehensive-income characteristics on nonprofessional investors' judgments: The role of financial-statement presentation format. The Accounting Review, Vol. 75 No. 2, pp. 179-207.

McCoy, T. L., Thompson, J. H., and Hoskins, M. A. (2009). Early evidence of the volatility of comprehensive income and its components. Academy of Accounting and Financial Studies Journal, Vol. 13 No. Summer, pp. 83-92.

Membership of IASB and FASB International Working Group on Performance Reporting Announced, 2004a.

Pronobis, P. and Zülch, H. (2011). The predictive power of comprehensive income and its individual components under IFRS. Problems and Perspectives in Management, Vol. 9 No. 4, pp.72-88.

Schroeder, R. G., Clark, M., and Cathey, J. (2001). Financial Accounting Theory and Analysis. 7th ed. John Wiley and Sons, New York, NY.

Skinner, D. J. (1999). How well does net income measure firm performance? A discussion of two studies. Journal of Accounting and Economics, Vol. 26 No. 1, pp. 105-111.

Yen, A. C., Hirst, D. E., and Hopkins, P. E. (2007). A content analysis of the comprehensive income exposure draft comment letters. Research in Accounting Regulation, Vol. 19 pp. 53-79. 